\title{
Prevalence of Herbal Use among Pregnant Women Attending Family Practice Center in El-Mahsama Village - Ismailia
}

Shereehan M. El-sayed ${ }^{1 *}$, Nadia M. Mansour ${ }^{2}$, Hebatallah Nour-Eldein ${ }^{2}$

${ }^{1}$ Minstry of Health, Ismailia Governorate

${ }^{2}$ Family medicine department, Faculty of medicine, Suez Canal University

\section{Abstract:}

Background: the popularity of herbal supplements has grown significantly in recent years. However, we have limited knowledge relating to why pregnant women use Integrative Medicine) and how this may relate to the provision of maternity care. Objective: This study aimed to assess the prevalence of the use of herbal medicine during pregnancy in El-Mahsama village, to find out the most common indications for which pregnant women use herbal medicine and to identify the most frequently consumed herbal medicine during pregnancy. Methods: This is a cross sectional descriptive study was conducted on 252 pregnant women attending antenatal care (ANC) clinic. Data were collected by researcher in interview with pregnant women to translate it from English to Arabic and writing the answers to avoid bias caused by illiterate women. Results: In the present study, prevalence of herbal use was $34.1 \%$, the most frequent herbs used by participants were; Fenugreek $(66.3 \%)$ followed by anise $(24.4 \%)$ then peppermint $(18.6 \%)$. the commonest indications of herbs were; colic $(77.9 \%)$, then cough\& flu (14\%). On the other hand, the most common method of use was decoction (98.84\%). Conclusions: The use of herbal medicine during pregnancy is a common practice in the rural area. There is a need to educate pregnant women about benefits and harms of herbal products and to train healthcare professionals on the available guidelines to herbal products used during pregnancy.

Keywords: Alternative medicine, Attitude, Complementary medicine, Herbal medicine, Integrative medicine, Pregnant women, Practice.

Introduction: The National Center for consumers of alternative medicines when
Integrative Medicine (NCCAM) defines compared with men In Italy, during the
alternative medicine as medical and health care systems, practices, and products that are not considered in conventional medicine practices. ${ }^{(1)}$ World Health Organization (WHO) define Herbs as crude plant material such as leaves, flowers, fruit, seed, stems, wood, bark, roots, rhizomes or other plant parts, which may be entire, fragmented or powdered. ${ }^{(2)}$ In the last decade, an important increase in the use of CAM has been observed in Europe, USA and Australia, in which most studies showed women as the major compared with men. In Italy, during the period 1997-99, almost nine million people used at least one non-conventional therapy. ${ }^{(3)}$

WHO estimates that about (80\%) of people living in Africa use traditional medicines for the management of their prevailing diseases. This high use of herbal medicines may be due to accessibility, affordability, availability and acceptability of traditional herbal medicines by majority of the population in developing countries. However, a number of herbs could cause adverse effects due to adulteration, inappropriate 
formulations, plant and drug interactions, effects that are sometimes life threatening or lethal. ${ }^{(4)}$ Some of the more complex reasons for preference of herbal medicines are associated with cultural and personal beliefs, philosophical views on life and health, as well as comparison of experiences between conventional healthcare professionals and complementary medicine practitioners by patients. $^{(5)}$

The use of herbal medicine has been on increase in many developing and developed countries. It is known that between $(65 \%)$ and $(80 \%)$ of the world's population use herbal medicines as their primary form of health care. Patients who are likely to be at risk from adverse effects of herbal medicines include those who are already prone to difficulties from regularly prescribed medications namely fetus, infants and older children, the elderly, as well as pregnant and lactating women. ${ }^{(4)}$ While pregnant women and their health care provides are increasingly aware that they should avoid unnecessary exposures during pregnancy, a paradoxical increase in the quantity of self-administered herbal and over the counter medication have been reported. ${ }^{(4)}$

Studies on herbal use in pregnancy have reported prevalence ranging from $7 \%$ to $96 \%$, most of them from developed countries. Studies have also reported different characteristics of women more likely to take herbal medicine in pregnancy. These included being older, married, primiparous, having tertiary education, being less educated and severity of nausea and vomiting. ${ }^{(4)}$

Methods: This is a cross sectional, descriptive study. The study was conducted in El-Mahsama village which situated about 25 kilometers from Ismailia Governorate, it is a rural area and providing services for 18000 people (According to the 2010 census issued by the central auditing organization), 2999 of them are at child bearing period that are my target in these study. The population in this community is cared by two health facilities (One is belonging to Ministry of Health and Population (MOHP) and the other one is Family Practice Center affiliated to the Faculty of Medicine Suez Canal University (FOM/SCU).

The study was conducted from December 2015 to December 2016. My study population are pregnant attended the two family practice centers of El-Mahsama village belonging to MOHP and FOM/SCU and accepted to share in the study were eligible to participate in the study. My sample size was 254 pregnant (after addition of $10 \%$ to compensate for dropout).Study population was allocated by convenient sample. A structured questionnaire was used previously 
in similar study by Saad,2012 designed to fulfill the study objectives. It was fulfilled by the researcher in interview with pregnant women to translate it from English to Arabic and writing the answers to avoid bias caused by illiterate women.

According to statistical analysis the obtained data were coded, entered and processed on a personal computer using Statistical Package of Social Science (SPSS). The appropriate statistical tests were used to identify significant difference. Chi square test was used for categorical data. Statistical significance were considered at $\mathrm{p}$-value $<0.05$.

Tools of the study: A structured questionnaire was used previously in similar study by Saad, 2012 designed to fulfill the study objectives. It was fulfilled by the researcher in interview with pregnant women to translate it from English to Arabic and writing the answers to avoid bias caused by illiterate women. It consists of three sections. The first section was concerned with the personal and socio-economic characteristics of the participants (age, gender, education, income of the family, smoking habits and coverage with health insurance of the respondent). The second section enquired about background, knowledge, use of herbs of the respondent and period of pregnancy. The third section was concerned to explore the belief of the respondent towards herbal therapy. ${ }^{(5,6,7)}$

Ethical considerations: The research proposal was approved by the ethical committee affiliated to faculty of MedicineSuez Canal University. Informed consent was obtained from the participants after explaining the objectives of the research. The questionnaires were anonymous but had code numbers. Confidentiality of data was maintained and the physicians were free to accept or not to participate in the research. Each participant was informed about the results of the study and was educated for the correct knowledge regarding the benefits and harms of herbal use during pregnancy. Counseling and medical services was provided to patient when needed.

Statistical analysis: The obtained data were coded, and processed on a personal computer using Statistical Package of Social Science (SPSS). The appropriate statistical tests were used to identify significant difference. Chi square test was used for categorical data. Statistical significance were considered at $\mathrm{p}$ value $<0.05$.

Results: Table (1) shows socio-demographic characteristics of the studied population;

The most frequent age group 19-24 years (49.6\%), while the less than 18 years old was (9.1\%), Preparatory/Secondary level was the 
main educational level (46.8\%) while university education represented only (4.8\%). The majority of participants were nonemployed (98.8\%). More than half of participants had less than 5 family members. On the other hand, $80.9 \%$ of participants had a perceived sufficient income. Figure 1 shows that the majority of studied women do not have enough knowledge about herbs (62.9\%), and only (37.1\%) have enough knowledge.

Figure 2 shows prevalence of herbal use among studied participants; it demonstrates that $34.1 \%$ of the studied population (pregnant women) had previously used herbs. Table 2 shows types of herbs used among surveyed women during the last year. The most frequent herbs used by participants were; fenugreek $(66.3 \%)$, peppermint $(18.6 \%)$ and Hibiscus (5.8\%); followed by Cinnamon $(2.3 \%)$. Figure 3: show the indications for herbal use among surveyed women in last year. Colic was the most common indication for herbal use among study population with a rate of $77.9 \%$, followed by cough and flu $(14 \%)$, stimulation of uterine contraction (5.8\%), hypotension (5.8\%), headache (3.5\%), nausea $(2.3 \%)$, and fatigue $(1.2 \%)$. Figure 4 shows outcome of herbs used by surveyed women in last year. Most of participant women has improved when used herbs $(90.7 \%)$, while $(7.0 \%)$, of them experienced no effect and a small proportion had aggravated symptoms $(2.3 \%)$.

Discussion: In the current study, regarding the prevalence of herbal use in the past years of their life, $34.1 \%$ of the studied population had already used herbal remedies in the past; the obtained result from the current study was in partial agreement with the reported result from a study conducted by Deema; (9) who studied herbal remedy taking by Rafidia citizens in Palestine; which showed that $40 \%$ of the studied population already used herbal remedies in the past; this agreement could be explained by the similarity of traditions and Arabic cultures.

The current study is in consistent with the study conducted in Egypt by Ibrahim Orief ${ }^{(10)}$ with the concepts of complementary and alternative practices in Alexandria governorate in which $27.3 \%$ of the studied population had used CAM at some time in the past of their life.Furthermore, in a study conducted by Hadayat ${ }^{(11)}$ in Jordan regarding self-therapy practices among Jordanian mothers focusing on herbal remedies; showed $73.8 \%$ of the respondents reported using herbal remedies in self-therapy.

The current study found that the most frequent herbs used by participants were; Fenugreek (66.3\%), anise (24.4\%), peppermint (18.6\%), Hibiscus (5.8\%), 
cinnamon $(2.3 \%)$. On the other hand the results obtained from another Egyptian study conducted by Yasser ; ${ }^{(10)}$ Studying the use of herbal medicines among pregnant women attending family health centers in Alexandria showed that the use of herbal/nutritional therapies was: anise $(40.2 \%)$, Fenugreek (31.7\%), Ginger(29.3\%), Garlic (22\%), Green tea $(19.5 \%)$.

In comparison with other studies: Malays study conducted by Azriani ${ }^{(11)}$ revealed that the most common herbal use is coconut oil (63.9\%), while Della study (12) reveals that the commonest herbal remedies are raspberry leaf (14\%), ginger $(12 \%)$ and chamomile $(11 \%)$.while the results obtained from the study conducted by Moussally ${ }^{(13)}$ revealed that Chamomile, green tea, peppermint and flax were the most frequently herbal product used. The most common herbs used in Deema's study were anise (61.7\%), chamomile $(53.3 \%)$, sage $(55 \%)$, mixture of herbs $(33.3 \%)$, and thyme (29.2\%). Another Jordanian study showed that al-Aniseed were the most commonly used (31.4\%) followed Sage (23.3\%), and Circuit (17.6\%). Al-Ginger was mentioned by $3.7 \%$ of users. ${ }^{(9)}$

Concerning the beliefs of usefulness of herbal therapy; the results of the current study found that that about $90.7 \%$ of participants believed in herbal usefulness. This result is in agreement with the results obtained from the study conducted by Azriani (14) during July 2008; regarding assessment of perceived efficacy of herbal remedies by users which revealed that the majority $(81.5 \%)$ who used herbal medicines during pregnancy believed that the herbal medicines were effective to solve their health problems and fulfilled the indications for use. In partial agreement with the result obtained from the study conducted by Yasser (10) between March and June 2011 for Use of herbal medicines among pregnant women attending family health centers in Alexandria; results showed that more than half of the studied pregnant women $(64.6 \%)$ reported the efficacy of herbal medicines in relieving their complaints during pregnancy.

Study Limitations: The obtained results cannot be extrapolated or generalized on the Egyptian community because the study was conducted only in a rural community. Further studies represent rural, urban and Bedouin communities are needed to give an overall view of herbal therapy use in Egypt.

Conclusion: The use of herbal therapy is a common practice among primary care patients. However, education on herbal therapy in terms of safety and effectiveness is a necessity must be achieved. The main challenges in the context of primary healthcare are to promote and upgrade the 
knowledge and skills of the providers about herbal therapy to ensure patient safety and to support patients in their self-management.

Conflict of Interest: There is no conflict of interest.

\section{References:}

1. National Center for Complementary and Alternative Medicine (NCCAM).What is complementary and alternative medicine (CAM)? Accessed at http://nccam.nih.gov/health/whatiscam /pdf. Last access date August 2017.

2. World Health Organization (WHO). Traditional Medicine: Definitions accessed in www.who.int/medicines/areas/traditional/ definitions/en/ . Last access date July 2018 .

3. Lapi F, Vannacci A, Moschini M, et al, Use, Attitudes and Knowledge of Complementary and Alternative Drugs (CADs) Among Pregnant Women: a Preliminary Survey in Tuscany, Evid Based Complement Alternat Med. 2010; 7(4): 477-486.

4. I. Tamuno, A. Omole-Ohonsi Fadare $\mathrm{J}$ : Use of Herbal Medicine Among Pregnant Women Attending A Tertiary Hospital In Northern Nigeria. The
Internet Journal of Gynecology and Obstetrics.2011; 15, 2.

5. Klepser T, Doucette W, Matthew R, et al. University of Iowa College of Pharmacy, Iowa City, Iowa. Assessment of Patients' Perceptions and Beliefs Regarding Herbal Therapies, 2000.

6. Abdelrahaman A, Sulaiman A, Ahmad.Z, et al. Prevalence and Pattern of Use of Herbal Medicines during Pregnancy in Tumpat District, Kelantan. Malays J Med Sci. 2008; 15: 40-48.

7. Saad.H. Patterns of herbal use among patients attending the primary health care centers at Fanara village, a thesis submitted for partial fulfillment of the requirement of master degree in Family Medicine, FOM SCU. 2012; 139-142.

8. Titilayo O, Rasaq A, Ismail E, Attitude and use of herbal medicines among pregnant women in Nigeria, BMC Complementary and Alternative Medicine 2009; 9:53 .

9. Adawi D. Prevalence and Predictors of Herb Use during Pregnancy (A study at Rafidia Governmental Hospital/ Palestine).2012; Pages: 92

10. Orief Y, Farghaly N, Ibrahim M et al. Use of herbal medicines among pregnant women attending family health centers in Alexandria. Middle 
East Fertility Society Journal. Volume

19, Issue 1. March 2014; Pages 42-50

11. Amasha H, Jarrah S. The Use of Home

Remedies by Pregnant Mothers as a

Treatment of Pregnancy Related

Complaints: An Exploratory Study.

Med. J. Cairo Univ., Vol. 80, No. 1.

2012 September; 673-680. Available

from:

www.medicaljournalofcairouniversity.co

$\underline{\mathrm{m}}$.

12. Forster D, Denning A, Wills G, et al. Herbal medicine use during pregnancy in a group of Australian women. BMC Pregnancy and Childbirth 2006, 6:21

13. Moussally K, Oraichi D, Bérard A. PubMed. Herbal products use during pregnancy: prevalence and predictors.2009 Jun; 18(6):454-61.

14. Abdelrahman A, Sulaiman, Ahmad Z, et al. Prevalence and Pattern of Use of Herbal Medicines During Pregnancy in Tumpat District, Kelantan. 2008 July; 15(3): 40-48. 
Table 1: Distribution of pregnant women according to their socio-demographic characteristics

\begin{tabular}{|c|c|c|c|}
\hline \multicolumn{2}{|r|}{ Characteristics } & \multirow{2}{*}{$\begin{array}{c}\begin{array}{c}\text { Frequency } \\
(\mathbf{N}=\mathbf{2 5 2})\end{array} \\
23\end{array}$} & \multirow{2}{*}{$\begin{array}{c}\text { percentage } \\
9.1 \%\end{array}$} \\
\hline Age groups & - $<18$ & & \\
\hline & - $19-24$ & 125 & $49.6 \%$ \\
\hline & - $25-49$ & 104 & $41.3 \%$ \\
\hline \multirow[t]{4}{*}{ Education } & - $\quad$ Illiterate/ Read \& Write & 107 & $42.8 \%$ \\
\hline & - $\quad$ Primary & 14 & $5.6 \%$ \\
\hline & - $\quad$ Preparatory/Secondary & 117 & $46.8 \%$ \\
\hline & - High Education & 12 & $4.8 \%$ \\
\hline \multirow[t]{2}{*}{ Employment } & - $\quad$ Employed & 3 & $1.2 \%$ \\
\hline & - $\quad$ Non-employed & 249 & $98.8 \%$ \\
\hline \multirow[t]{2}{*}{ Family Size } & - 2 - 4 individuals & 206 & $81.7 \%$ \\
\hline & - 5 - > 6 individuals & 46 & $18.3 \%$ \\
\hline \multirow{2}{*}{$\begin{array}{l}\text { Family } \\
\text { Income }\end{array}$} & - $\quad$ Perceived as sufficient & 203 & $80.9 \%$ \\
\hline & - $\quad$ Perceived as Insufficient & 48 & $19.1 \%$ \\
\hline
\end{tabular}

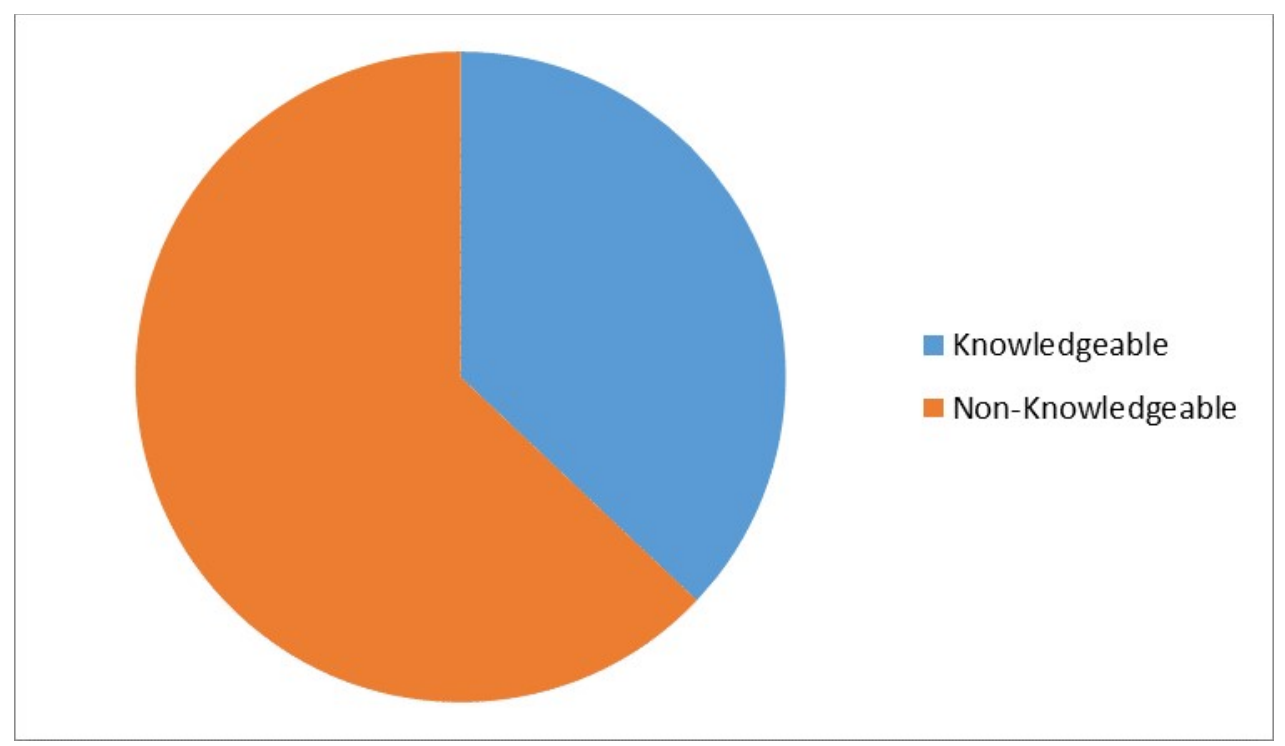

Figure 1: Distribution of studied women according to knowledge about herbs 


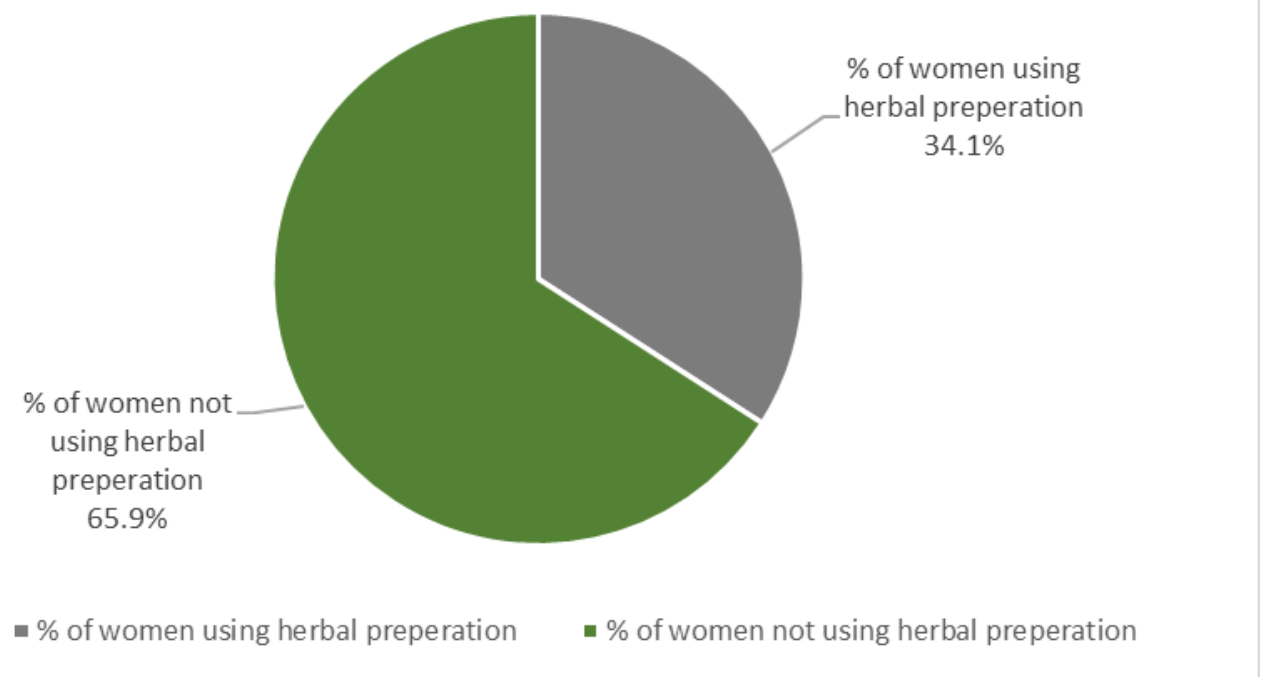

Figure 2: Prevalence of herbs use among studied women over the past

Table 2: Types of herbs used among women using herbs over the past year $(\mathrm{N}=86)$

\begin{tabular}{|c|c|c|c|c|}
\hline English name & Latin name & Arabic name & $\begin{array}{c}\text { Total number } \\
\mathbf{N}=86\end{array}$ & Percentage \\
\hline - $\quad$ Fenugreek & FænumGræcum & 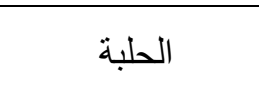 & 57 & $66.3 \%$ \\
\hline - peppermint & Caromenta, Menta & ن عناع & 16 & $18.6 \%$ \\
\hline - Hibiscus & Roselle & كركدية & 5 & $5.8 \%$ \\
\hline - Cinnamon & Canella, Cinnamomum & قرفة & 2 & $2.3 \%$ \\
\hline - $\quad$ Black Seed & Levasticum & حبة البركة & 1 & $1.2 \%$ \\
\hline - Caraway & Careum & كروياء & 1 & $1.2 \%$ \\
\hline - Garlic & Allium & ثوم & 1 & $1.2 \%$ \\
\hline - Dill & Anethum & شبت & 1 & $1.2 \%$ \\
\hline - $\quad$ Fennel & Finiculum & شمر & 1 & $1.2 \%$ \\
\hline $\begin{array}{ll}\text { Others } \\
\text { (Anise,...) }\end{array}$ & Anise & ينسون & 21 & $24.4 \%$ \\
\hline
\end{tabular}




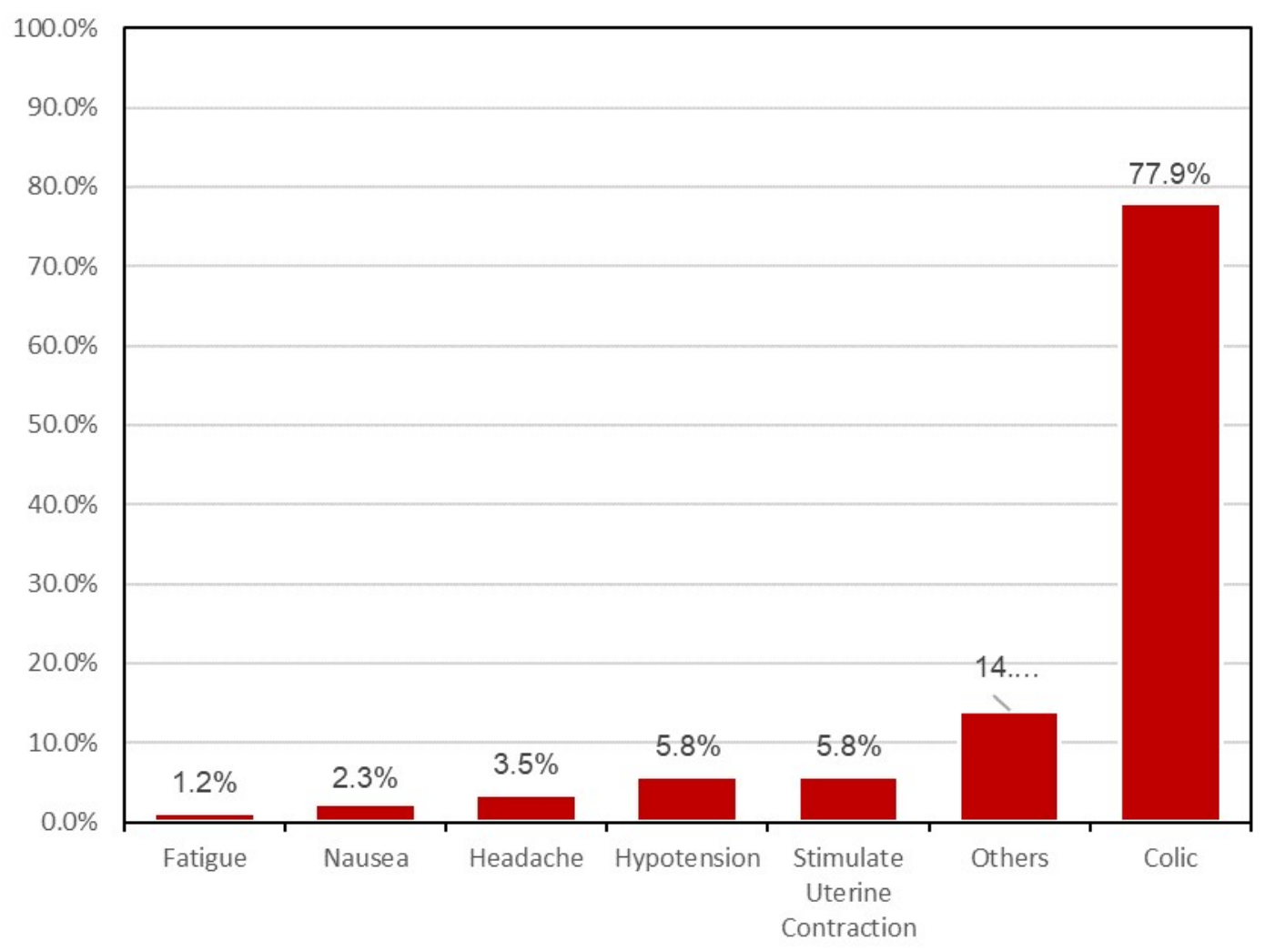

Figure (3): Indications of herbal use among studied women over the past year.

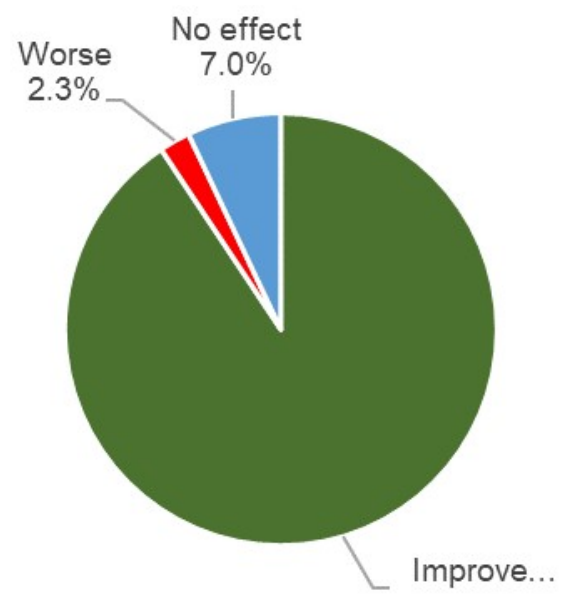

Figure (4): Outcome of herbs used by studied women over the past year 
معدل انتشار استخدام الأعثاب بين السيدات الحوامل المترددات علي مراكز الرعاية الصحية الأولية بقرية المحسمة القديمة بالاسماعيلية

شيرين السيد ـ ناديه مبروك منصور - هبه الله نور الدين

الخلفيه: لاعشاب الطبية هي نباتات لها خصائص علاجية للامر اض المختلفة، وكذلك في الحفاظ على صحة الانسان والحيوان. اكبر ميزة للاعشاب هي انها تشكل علاجا طبيعيا 100 ٪. الاعشاب هي عنصر اساسي في الطب الصيني. في الهجتمات غير الصناعية يعتبر طب

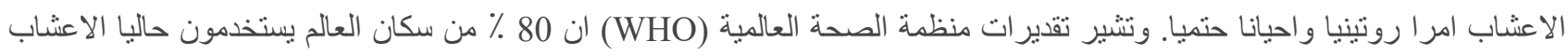

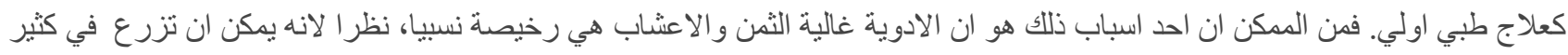
من الاحيان من بذور تم جمعها في البرية او تم شراؤها بثمن بخس. الأهداف: هذه دراسة وصفية لتحديد نسبة استخدام الاعثاب و العو امل المتعلقة باستخدام العشب ، تحديد اشهر الاعشاب المستخدمة والامر اض المستخدم لها وتحديد العوامل المؤثرة علي استخدام الاعثاب بين السيدات الحوامل. المنهجيه وطرق البحث:هذه الدراسة الوصفيه أجريت علي السيدات الحوامل والبالغ عددهن 252 سيدة حامل و المترددات علي مركزين لطب اسرة أحدهما يتبع وزارة الصحة والاخر يتبع كلية الطب جامعة قناة السويس. النتائج: اظهرت الدراسه ان نصف السيدات محل الدراسه تقريبا حاصلين علي تعليم اعدادي- ثانوي (8و46\%) و معظمهن لا يعملن(8و98\%) كما ان معظم افراد اسرهن اقل من 6أفراد وكذللك(9و 80) منهن يتمتعن بمستوي معيشة كافي.نسبة استخدام الاعشاب في الدراسة الحالية (1و34\% ). اكثر الاعشاب استخداما هو : الحلبة (3 و66\%) و الينسون (424\%) ثم النعناع (6و18\%). اكثر اسباب استخدام الاعشاب شيو عا هو المغص (9و 77\%) ثم نزلات البرد والكحة(14\%). علي الجانب الاخر فان اشهر الطرق اعداد الاعثاب هو الغليان (898\%) (98.84\%).بالنسبة لمعتقدات السيدات المشتركات: الدراسة الحالية اثتتت ان (7و90\%) منهن يعتقدن ان الاعثاب مفيدة للصحة، و علاوة علي ذلك فإن (5و92\%) تكون اسرتها واقاربها هم اكبر مصدر

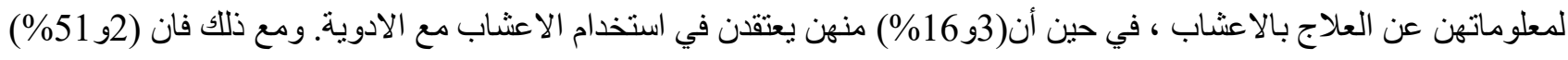
يعتقدن أن الأعشاب هي أفضل من الدواء. الخلاصه والتوصيات:خلصت هذه الدراسه الي ان استخدام العشاب باشكالها المختلفه منتشر لدي السيدات الحوامل ويوصى باجر اء البحث علي نطاق اوسع في قطاعات الريف و الحضر. 